\title{
Zespół dworsko-folwarczny w Kutnie w świetle inwentarza z 1695 roku
}

The Manor and Grange Complex in Kutno According to the 1695 Inventory

\begin{abstract}
Abstrakt: Przekazy źródłowe dotyczące dziejów Kutna w okresie poprzedzającym schyłek XviII w. nie są zbyt liczne. Dodatkowo zaledwie w kilku z nich znaleźć można informacje o funkcjonującej tam wówczas siedzibie pańskiej. Najwięcej mówią nam o nich trzy przekazy - jeden pochodzący z 1503 (lub 1502) oraz dwa z 1695 r. Z pierwszego dowiadujemy się, iż $\mathrm{z}$ jedną z dwu włości, na jakie podzielone było
\end{abstract}

wówczas miasto, związana była curia seu fortalicio, a więc obiekt obronno-rezydencjonalny. Z kolei drugi (1695) przynosi nam obszerny opis położonego nad brzegiem rzeki Ochnia założenia dworsko-folwarcznego, sporządzony w kilka lat po przejęciu go przez Zamoyskich, a trzeci (także i695) uzupełnia go o wiadomości odnoszące się do prac remontowych i budowlanych prowadzonych tam pod koniec XVII w.

Słowa kluczowe: średniowiecze, nowożytność, Kutno, dwór alkierzowy, folwark, zabudowania mieszkalne, zabudowania mieszkalno-gospodarcze, zabudowania gospodarcze, zabudowania przemysłowo-gospodarcze, zabudowania usługowe

Kutno, duże powiatowe miasto leżące w północnej części województwa łódzkiego swą dzisiejszą pozycję zawdzięcza szybkiemu rozwojowi w drugiej połowie XIX w., będącemu skutkiem poprowadzenia w jego najbliższym sąsiedztwie linii kolei żelaznej łączącej Warszawę z Bydgoszczą. W chwili, gdy linia ta docierała przed I grudnia I86I r. do Kutna było ono jeszcze prywatną własnością Feliksa Mniewskiego. Pozostało nią zresztą jeszcze przez kilka kolejnych lat, aż do wykupienia w latach 1863-1866 przez skarb państwa ciążących na mieszczanach powinności i czynszów z rąk kolejnego dziedzica Witolda Mniewskiego (Hilchen I912: 247; Józefecki 2002; Latos 2002: 363; Kita 201ra: 242). Ten zaś pozostał nadal posiadaczem wiejskiej części dóbr kutnowskich, w tym i osady Gierałty wraz z wznoszącym się tam dworem (zazwyczaj określanym mianem pałacu), od kilkudziesięciu lat już wówczas stanowiącym siedzibę właścicieli tej majętności.

Dwór ten, choć dość znacząco przekształcony, istnieje do dziś, a w prawie całej dotychczasowej literaturze przyjmuje się, iż powstał on w latach $178 \mathrm{I}-1785$. Jako pierwsi datowanie takie jako prawdopodobne sformułowali Eleonora Bergman 
i Jacek Jernajczyk (Bergman i in. 1980, I: 47, 54 /przyp. 54/; 2: 18, 25/przyp. 55/)1. Dla uzasadnienia swej propozycji przywołali przy tym odnoszącą się do pałacu w Świacku pracę Władysława Tatarkiewicza (1937). Pogląd ten ze wskazaniem tego samego źródła ${ }^{2}$ lecz już jako uznaną prawdę upowszechniła Grażyna Majewska [ $2{ }^{0}$ voto: Kin-Rzymkowska] (1984: 362; 1997: 102, 105, 135; 2011: 454), a za nią powtórzyli m.in. Henryk Lesiak (2007: 33), Irena Januszczak (2007: 475), Piotr A. Stasiak (20I2: 117-II8) i Andrzej Latos (20I5: 12). Jest to jednak nieporozumienie, gdyż we wspomnianym tekście nie znajdujemy nic, co pozwoliłoby na przyjęcie właśnie tak wyznaczonych ram chronologicznych budowy dworu w Kutnie. Dowiadujemy się zeń jedynie, iż mające funkcjonować również i w tym wypadku rozwiązanie w typie w zapoczątkowanym przez Palladia, w którym

korpus główny połączony [jest - dop. JP] z oficynami przez koliście poprowadzone kolumnady [...] w dobie klasycyzmu [...] doszło do Rosji, zapoczątkowane tam przez Camerona w Pawłowsku w latach $178 \mathrm{I} / 5$, a rozpowszechnione szczególniej przez Kozakowa w Moskwie. W tym samym czasie dostało się do Polski: najwcześniejsze jego zabytki przypadają na drugą połowę panowania Stanisława Augusta, ale większość już na czasy porozbiorowe (Tatarkiewicz 1937: 7-8 /przyp. I/; zob. też 1966: 210/przyp. I/).

Dodatkowo wydaje się, że również przypisanie przez E. Bergman i J.Jernajczyka inicjatywy podjęcia budowy dworu Stanisławowi Gadomskiemu jest jedynie konsekwencją wynikającą z zaproponowania wspomnianych wyżej lat jego budowy (Bergman i in. 1980, 1: 26, 47; 2: I8; Majewska [ ${ }^{0}$ voto: Kin-Rzymkowska] 1984: 362; 1997: 102, I05, 135; 2011: 454). Możliwe jednak, iż domysł ten nie mija się z prawdą, gdyż choć - jak zauważyła Hanka Żerek-Kleszcz - folwark Gierałty nie został wspomniany w 1776 r. przy okazji rezygnacji z dóbr kutnowskich przez Andrzeja Zamoyskiego (byłego kanclerza wielkiego koronnego oraz późniejszego X ordynata zamojskiego) na rzecz S. Gadomskiego (AGAD, MK 293: IOov; Żerek-Kleszcz 2002: 117 /przyp. 6/3), to bez większych wątpliwości sądzić można, iż to o nim wspominał ten ostatni przy okazji swych starań o urząd wojewody

1 Wcześniej Dariusz Kaczmarzyk, autor noty w Katalogu Zabytków Sztuki w Polsce, ograniczył się do podania, iż pałac został Zbudowany w końcu w. XVIII (Powiat kutnowski... 1954: 31).

2 A właściwie jego ponownego, nieznacznie zmienionego wydania (Tatarkiewicz 1966: 210 /przyp. I/).

3 Nie pojawia się on również wśród dokumentów z lat 1696-1742 odnoszących się do będących wówczas w posiadaniu Zamoyskich dóbr Kutno, zebranych w związku z pretensjami do tejże majętności starosty tłumackiego Eustachego Potockiego (AGAD, APR I53; por. Orłowski 1965: 192). 


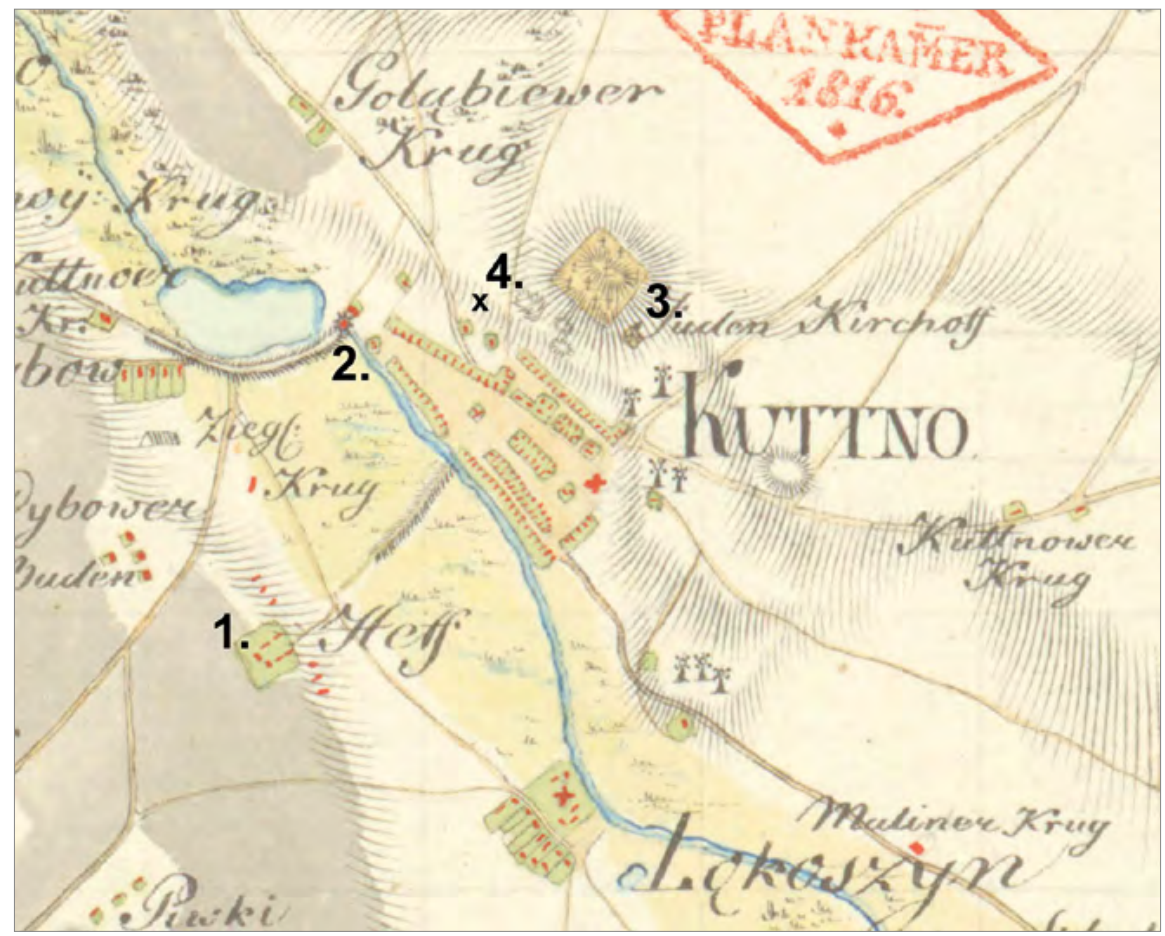

Ryc. 1. Kutno i okolice - wycinek mapy z I793-1796 r., za: SSB PK, Kart N I443I: Bl. XXXVIII I. Gierałty; 2. folwark nad Ochnią; 3. folwark „górny”; 4. przybliżona lokalizacja „ruiny zamku”. Skala org. ca. I : 50 ooo.

łęczyckiego, pisząc w 1787 r. w liście do króla, ...samo moje miasteczko Kutno, tak jest na granicy województwa tęczyckiego, że już moja rezydencja, gdzie mieszkam i wiosek kilka należących jest w województwie tęczyckim... ${ }^{4}$. W niej to w następnym roku odbyła się uroczysta gala poprzedzająca wjazd nowego wojewody do Łęczycy (Żerek-Kleszcz 2002: II9, I24). Trudno jednak powiedzieć, czy S. Gadomski dysponował tu już wówczas murowanym dworem, czy też powstał on dopiero później, może nawet już po przejęciu majętności przez Walentego Rzętkowskiego, czy nawet władającego nią już w lipcu 1791 r. (Kita 20ıı: 235; Kobierecki 20ı1: I85). Ponieważ jednak założenia „typu palladiańskiego” powoli traciły swą popularność dopiero w pierwszej ćwierci XIX w., a pierwszym świadectwem istnienia kutnowskiego dworu w takiej właśnie postaci jest schematyczny rysunek

4 Słowa te w pewnej mierze może uprawdopodobniać fakt, iż w miejscu lokalizacji gierałtowskiego założenia dworsko-folwarcznego na sporządzonej w 1793-1796 mapie Davida Gille'go odnotowano punkt osadniczy opisany jako „Hoff” (sBB, PK, Kart N I 443 I: Bl. XXXVIII). 
na pochodzącym z I826 r. planie przedłużenia ówczesnej ulicy Zamkowej', możliwe nawet (choć to raczej mało prawdopodobne), iż dwór powstał dopiero, gdy dobrami władali Franciszka i Antoni Gliszczyńscy, tj. córka i zięć W. Rzętkowskiego († 2 lutego I8ı3) (Kita 20ıra: 237-238). Co więcej, nie da się wykluczyć, iż do podjęcia jego budowy doszło dużo wcześniej, tj. jeszcze za czasów Andrzeja Zamoyskiego, a więc przed 1776 r. Pamiętać bowiem należy, iż jego starszy brat Jan Jakub (IX ordynat zamojski) był inicjatorem rozpoczętej nie wcześniej niż w 1748 r. i dość szybko chyba ukończonej budowy rokokowego pałacu w Łabuniach, w trakcie której powstała najwcześniejsza najpewniej w Rzeczypospolitej rezydencja z palladiańskimi, ćwierćkolistymi galeriami łączącymi korpus główny z oficynami. Stał się on ulubioną siedzibą Jana Jakuba, bywał tam również i Andrzej, rozwiązanie takie nie było mu więc obce (m.in. Kurzątkowska 1963; Orlowski 1965: 233 /przyp. 9/, 248-250/przyp. 44-47/; Jaroszewski 1966: I86-I87; 1968: 149-150; Kowalczyk 2003: 103-1066). Wiemy też, iż odebrał staranne, głównie zagraniczne wykształcenie, pobierając również nauki w zakresie architektury civilis et militaris (Orłowski 1965: 3-5; Michalski 1974: 7-8). Nie wiemy natomiast, czy edukacja ta wywarła jakiś wpływ na jego późniejszą działalność na tym polu. Na dzisiejszym etapie poznania wydaje się jednak, iż swymi dokonaniami nie dorównywał pod tym względem swym starszym braciom Tomaszowi Antoniemu (vil ordynatowi zamojskiemu) i wspomnianemu już Janowi Jakubowi (o ich działalności zob. Kowalczyk 1959; 2003). Wydaje się bowiem, iż jego działania przed przejęciem ordynacji zamojskiej ograniczały się do przeprowadzenia po I767 r. regulacji zabudowy trzech należących do niego miast mazowieckich (Bieżunia, Kutna i Żuromina), a także do odbudowy po pożarze z 1753 r. murowanego kościoła w Kutnie, budowy murowanych świątyń w Żurominie (1757/1760?-1773 i 1778-1783/1784) i Bieżuniu (po 1764-1776/1778?) oraz budowy bliżej nieokreślonych domów dla mieszczan w Bieżuniu, wzniesienia po pożarze z 1774 r. murowanych (częściowo?) mieszczańskich domów w Kutnie (Orłowski 1965: 194; Bergman 1995: 32, 34; Małowiecki 1995: 46, 53). W tym ostatnim miał też wystawić murowane gmachy ratusza i austerii. Możliwe też, iż to już wówczas powstał murowany spichlerz w tzw. „górnym” folwarku - przy obecnej ul. Bema. Wreszcie też przebudował swą ulubioną siedzibę, tj. bieżuński dwór/pałac (gdzie budowano w 1776 r. kaplicę) (x.R.F. 1894: 599-600; Orłowski 1965: 194; Kobierecki

5 Jej przebieg został przerwany w i86I r. w efekcie budowy torów kolei Warszawsko-Bydgoskiej (Hilchen 1912: 247; Latos 2002: 362). Dziś jej odpowiednikiem są ulice: Pałacowa i Henryka Sienkiewicza.

6 Ten ostatni badacz dopuszczał dawniej, iż galerie w Łabuniach powstać mogły w efekcie prac prowadzonych przy tym obiekcie po opuszczeniu go przez kwaterującą w nim rosyjską piechotę walczącą z konfederatami barskimi (Kowalczyk 1959: 223-225). 


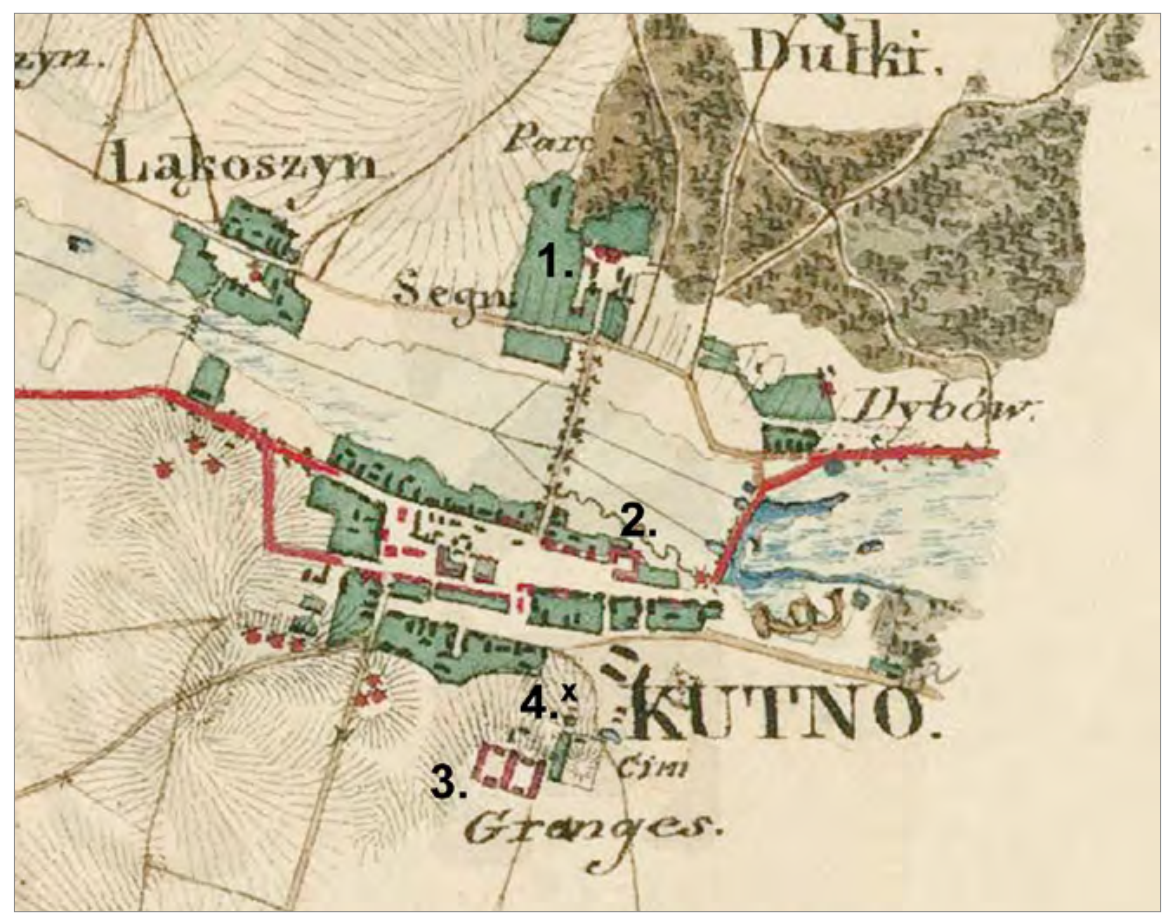

Ryc. 2. Kutno i okolice - wycinek mapy z I825 r., za: AGAD, ZGSA: AK I57, ark. [VIII].

I. Gierałty; 2. folwark nad Ochnią; 3. folwark „górny”; 4. przybliżona lokalizacja „ruiny zamku”. Skala org. I : 84 ooo.

20II: 199; Majewska [ ${ }^{0}$ voto: Kin-Rzymkowska] 1984: 36r; 20II: 452). Poza nią dysponował A. Zamoyski również pałacem na podwarszawskim Lesznie, a ponieważ Kutnu poświęcał dużo uwagi i często w nim bywał (Orłowski 1965: 115, 190) można się spodziewać, iż i tu posiadał jakąś siedzibę. Niestety, żaden jednak przekaz nie mówi nam nic o jej wyglądzie.

Niewiele wiemy też o dworach funkcjonujących w Kutnie wcześniej. Wynika to z faktu, iż źródła dotyczące dziejów tej osady w okresie poprzedzającym schyłek XVIII w. nie są zbyt liczne. Dodatkowo zaledwie w kilku z nich znaleźć można informacje o funkcjonującej tam siedzibie pańskiej, a i te z reguły praktycznie poświadczają tylko jej istnienie (zob. np. Nowak 20II: I44).

Wyjątkami są tu jedynie trzy przekazy - jeden pochodzący z I503 (lub I502) i dwa z 1695 r. Lecz i w ich wypadku ilość dostarczanych informacji jest różna.

I tak z pierwszego przekazu dowiadujemy się, że z Kutnem związany był obiekt określony jako dwór albo fortalicja (curia seu fortalicio - AGAD, GErel. II: I62v). A ponieważ w tym często spotykanym w średniowiecznych i wczesnonowożytnych źródłach określeniu łaciński termin curia, będący m.in. odpowiednikiem 
polskiego słowa dwór (rozumiany jako pański budynek mieszkalny, z podwórzem i zabudowaniami gospodarczymi), nakłada się na fortalicium, tłumaczone zazwyczaj jako mata forteca, rzadziej zaś jako strażnica, możemy widzieć w tak nazwanym obiekcie dwór o mniej lub bardziej zaznaczonych walorach obronnych, a więc obiekt o charakterze obronno-rezydencjonalnym (Pietrzak 2003: 20-22; Kajzer 2010: 43-44; Poliński 2018: 49-50).

Obiekt ten był wówczas w posiadaniu wojewody rawskiego Andrzeja z Kutna, który, zbliżając się do kresu swego życia i decydując o przyszłym podziale (losowym) swych dóbr między synów, na centrum jednego z działów wyznaczył połowę Kutna. Druga połowa miasta, należąca niegdyś do jego brata Mikołaja († I493), była już wówczas w rękach jego spadkobierców. Sam Mikołaj był najwybitniejszym chyba przedstawicielem rodziny Kucieńskich, który zyskał przychylność króla Kazimierza Jagiellończyka przede wszystkim tym, iż jako starosta gostyniński z ramienia książąt mazowieckich doprowadził do przejścia rycerstwa ziemi gostynińskiej na stronę królewską, a w efekcie, w I462 r., do jej inkorporacji do Korony. Jako bliski współpracownik króla uczestniczył w misjach dyplomatycznych, a także piastował szereg urzędów - był dożywotnim starostą gostynińskim, wojewodą rawskim (I465-I467), tęczyckim (I467-I493). W I484 r. został też starostą generalnym Wielkopolski, a w latach $\mathrm{148}$ I-I 492 trzymał starostwo wieluńskie (Gąsiorowski 1971: 63-65; Pacuski 2009: 165-166; Nowak 2011: 139-I40; Parol 2019: 100-10I, I46-147).

Kutno było więc $w$ tym czasie ośrodkiem dwu możnowładczych zespołów dóbr ziemskich, a w przypadku podziału majętności jedną z najbardziej znaczących zmian mogło być, jak sądzimy, utworzenie drugiego folwarku, a także wzniesienie drugiej związanej z posiadaczami Kutna siedziby pańskiej. O możliwości takiej wspomniała w 1980 r. E. Bergman, która lokalizowała siedzibę Kucieńskich na północnym brzegu Ochni, w pewnym oddaleniu, na zachód od rynku. Jednocześnie sądziła, iż po przeciwnej stronie Ochni [...] w miejscu, gdzie w XVIII w. postawiono patac, a więc na Gierałtach, powstać mogła siedziba właścicieli drugiej połowy miasta. W innym miejscu badaczka ta zwróciła uwagę na masywną ruine d. lodowni czy też browaru, wznoszącą się niegdyś już poza granicami miasta z początku XIX w., w miejscu oddalonym o 350-400 m na północny wschód od proponowanego przez nią miejsca lokalizacji siedziby Kucieńskich, określaną w materiałach konserwatorskich jako ruina zamku XV-wiecznego (Bergman i in. I980, I: 20-2I, 40, 60/przyp. I57/). Nie rozwijała jednak szerzej tego wątku, zapewne wobec niemożności weryfikacji tego przekazu - bowiem ten sam obiekt Zbigniew Ciekliński datował na XVI w. - po wysadzeniu 1969 r. przez saperów ruin w powietrze dla umożliwienia wzniesienia w tym miejscu domu kultury (Ciekliński 1954: 282-283; Bergman i in. 1980, I: 40, 60 /przyp. 157/; patrz też Kajzer 1987; 1998; Majewska 1997: 100-IOI; Czekalska 1999: 137-I38). 


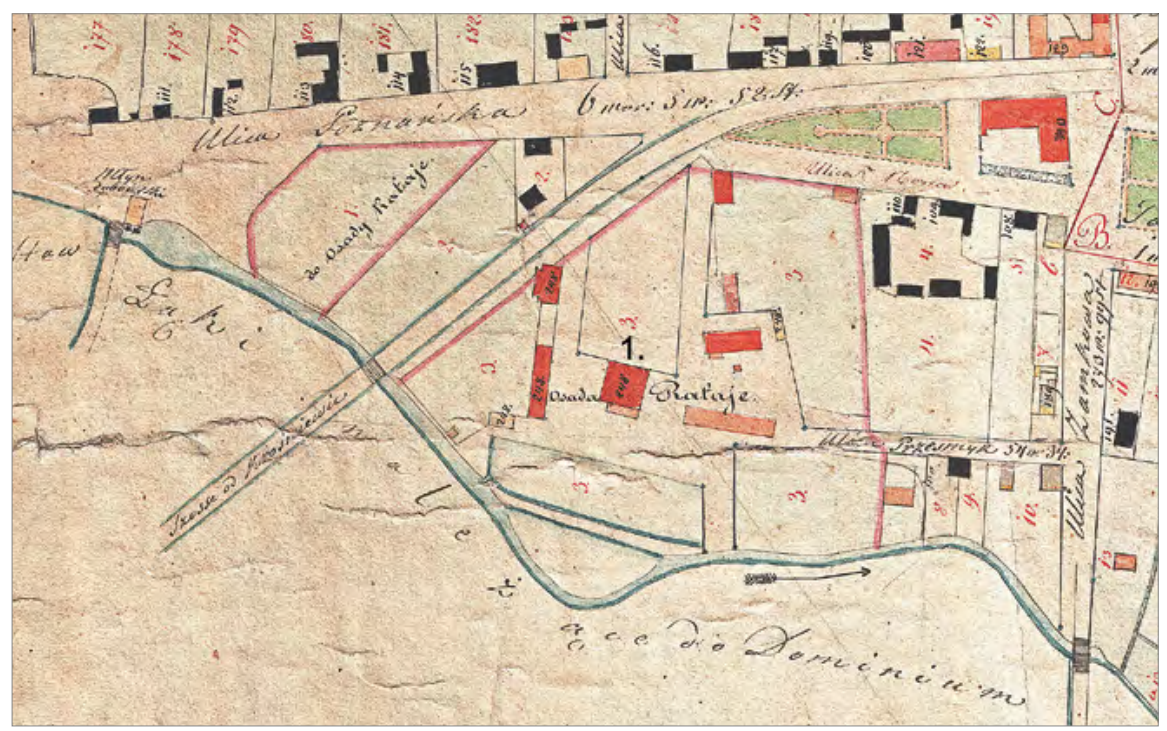

Ryc. 3. Zabudowania na obszarze folwark nad Ochnią - wycinek mapy z I825 r., za: ZAP: U. II. 75 I. budynek identyfikowany z murowanym, wczesnonowożytnym dworem. Skala org. I : 2500 .

Z kolei drugi przekaz (I695) to inwentarz majętności kutnowskiej (AGAD, GErel. I70: 54I-547 $\mathrm{v}^{7}$ ) sporządzony w kilka lat po tym, jak w i689 r. jej właścicielką została Anna Zamojska z Gnińskich, która, skupując już jako wdowa poszczególne części miasta i dóbr kutnowskich, doprowadziła do ponownego scalenia ich w jedną obszerną włość. Jednak, jak się wydaje, tylko przez jakiś czas zarządzała nią bezpośrednio przez swych pełnomocników, później zaś oddawała je w krótkoterminową dzierżawę. Właśnie przy takiej okazji sporządzony został interesujący nas inwentarz, zawierający m.in. dość dokładny opis zabudowań dworskich w Kutnie (AGAD, GErel. 170: 545-546v). W tym samym czasie spisano także trzeci z interesujących nas przekazów, dołączony wtórnie do innego, późniejszego o 20 lat kontraktu, w którym zeznający świadkowie podają m.in. nieco informacji dotyczących tychże zabudowań (AGAD, APR I53: III-II6), a jeden $\mathrm{z}$ nich podaje, iż zgodnie z jego wiedzą wznosiły się na przestrzeni od bramy a ż do brzegu [podkreślenie JP], który zdaniem E. Bergman jest zapewne brzegiem rzeki Ochni. Dodatkowo zarówno inwentarz, jak i inni zeznający wspominają

7 Jego zawartość została krótko omówiona przez L. Kajzera (1989: 45I-452; 1998: 13-16), a częściowo również Michała Kobiereckiego (2011: 189-190, 202). Dodatkowo pierwszy z nich opublikował (z drobnymi, zasadniczo nieistotnymi pomyłkami) w formie aneksów opis zabudowań dworskich (Kajzer 1989: 451-452, 459-462; 1998: 13-16, 30-36). 
też o mieszkających przed dworem ratajach oraz chałupach ratajskich, a właśnie nad brzegiem tej rzeki na mapach Kutna powstałych u schyłku XVIII i w początkach XIX w. doszukiwać się można zespołu zabudowań należących do domeny dworskiej i to położonych w rejonie określanym na jednej z nich mianem „Osada Rataje" (AGAD, APR I53: I13, II5; AGAD, GErel. 170: 545-546v; AGAD, ZGSA, AK 177: VIII; SBB, PK, Kart N I443I: XXXVIII; ZAP: U. II. 75.; Bergman i in. 1980, I: 23; Kobierecki 20II: I80-I8I, I88-I89). W tej sytuacji można przyjąć, iż opisywany w inwentarzu zespół dworsko-folwarczny wraz z sąsiadującymi zeń zabudowaniami ratajskimi zajmował teren położony w odległości około $650-850 \mathrm{~m}$ na zachód od kościoła parafialnego, a rozciągający się pomiędzy ciągnącym się od północy traktem poznańskim (w przybliżeniu odpowiadającym dziś ulicy Gabriela Narutowicza) od północy, korytem płynącej od południa i południowego zachodu Ochni oraz linią biegnącą „równolegle” od dzisiejszej ulicy i Maja, nieco jednak na wschód od niej. Generalizując, był to teren leżący na południe i południowy zachód od dzisiejszego Ronda "Solidarności”, a tworzące właściwy zespół budynki wznosiły się w jego wschodniej partii (por. Bergman i in. 1980, I: 20; Majewska [2 ${ }^{0}$ voto: Kin-Rzymkowska] 1984: 359; 1997: 100, 135; 2011 : 444-445). Były one prawie bez wyjątku drewniane, z opisu nie dowiadujemy się zazwyczaj jednak nic o ich konstrukcji. Budynki te funkcjonowały w obrębie dość obszernego zapewne podwórza, wygrodzonego po części parkanem, po części ostrokołem, a po części także bliżej nieokreślonym ogrodzeniem - może np. płotem z żerdzi czy dyli ${ }^{8}$. Dostęp na nie wiódł od traktu poznańskiego, zapewniały go zaś wrota z tarcic oraz przyległa do nich furta. Te pierwsze osadzone zostały na biegunach, podczas gdy furtę zawieszono na żelaznych zawiasach. Były też one zaopatrzone w żelazne zamknięcia (kunę, skoble i wrzeciądz) (AGAD, GŁrel. 170: 545). Po ich przebyciu opisujący obiekt rewizor doszedł do wznoszącego się w północno-wschodniej części zespołu starego, piętrowego spichlerza, tak zdekapitalizowanego, że - w opinii lustratora - powinien zostać rozebrany ${ }^{\mathrm{i}}$ dotarł do starego, poszytego gontem i wymagającego remontu dworu. Ten zaś - jak wynika z opisu - był budynkiem o dość rozbudowanej bryle, gdyż najpewniej zaopatrzono go w co najmniej trzy - a raczej nawet cztery - narożne alkierze. Pierwszym (dalej jako /r./) z nich była dobudówka, w której mieściło się secretum [ustęp - uw. JP] i poboczna komorka dawno zbudowana pod starym przykryciem, bez powaty. Dwa kolejne zostały w przekazie nazwane altankami.

8 Wydaje się przy tym, iż parkan założono od północnego-wschodu oraz północy, tj. od strony miasta oraz traktu poznańskiego.

9 Mimo to podano, iż W tym spiklerzu drzwi dwoje z skoblami i wrzeciadzami, na zawiasach, podtogi obiedwie $z$ tarcic i powata, dach stary, gontami pobity, ale zty, trzeba inszgo (AGAD, GErel. 170: 545). 
Jedna (dalej /2./) z nich określona została mianem spustoszatej [...] o trzech ścianach; druga (dalej /3./) określona jako dawna, a teraz służąca za sionkę wiodącą z izby stołowej na podwórze. Wreszcie, czwartego alkierza (dalej /4./) można się dopatrywać $\mathrm{w}$ skomunikowanym drzwiami ${ }^{10} \mathrm{z}$ izbą stołową pokoju, który spustoszat, nad którym znajdowała się kolejna, również spustoszała altanka. Nie można jednak wykluczyć, iż pokój ten był lokalnością mieszczącą w obrębie korpusu dworu, przy czym zdecydowanie bardziej prawdopodobnym jest pierwsze z zaproponowanych rozwiązań. W tym wypadku wydaje bowiem się, iż mamy do czynienia z dwukondygnacyjnym alkierzem przewyższającym swą wysokością korpus główny dworu, w zredukowanej zapewne formie, nawiązującym do dwukondygnacyjnych alkierzy znanych choćby z projektów Tylmana z Gameren i Giovanniego Battisty Gisleniego. Co więcej, w twórczości tego ostatniego można znaleźć również rozwiązania proponujące umieszczenie wieżowej formy wejściom, a taką mógł w naszym dworze przybrać usytuowany najpewniej na osi fasady ganek z kamienną posadzką i pokryciem z gontów, na którym inwentaryzator dostrzegł kolejną altankę (AGAD, GÆrel. 170: 545; SKD, KK: Ca 67/48v; Mossakowski 1973: 49, il.311; 2012: 31, il.287, 288; por. Sikorska 1991: 27).

Mimo tego przekonania, wobec braku pewności, analiza opisu budynku pozwala stwierdzić jedynie, że korpus obejmował pięć albo sześć pomieszczeń, rozmieszczonych w trzech dwutraktowych (przynajmniej w części) pasmach. I tak na jego osi mieściła się dostępna z zewnątrz przez ganek sień, która rozprowadzała ruch wewnątrz dworu. W ścianie na lewo od wejścia głównego znajdował się otwór drzwiowy, który prowadził do jednego z dwu wzajemnie skomunikowanych ze sobą odnowionych pokoi (tarcicami nowemi obite) zajmujących narożniki budynku. $Z$ pokoju położonego od frontu można było przejść do alkierza określonego wyżej jako pierwszy /I./, a z leżącego w trakcie tylnym dostać się do alkierza $/ 2 .{ }^{11}$ oraz wyjść na zewnątrz do ogródka. Z kolei otwór drzwiowy w prawej ścianie sieni umożliwiał wejście do izby stołowej skomunikowanej - o czym wyżej już wspomniano - zarówno z alkierzem oznaczonym jako /3./, jak i z spustoszatym pokojem, a więc alternatywnie albo alkierzem 4., albo po prostu pomieszczeniem położonym w trakcie tylnym pasma prawego. Wreszcie kolejne przejście z izby stołowej wiodło do kolejnej lokalności określonej mianem pokojuśredniego. Ten zaś mógł zajmować trakt tylny w paśmie środkowym, jak i sąsiadować w paśmie prawym ze spustoszatym pokojem (AGAD, GŁrel. 170: 545).

10 A dokładniej skomunikowanym niegdyś, bo w momencie spisywana inwentarza drzwi te były zabite (AGAD, GErel. 170: 545).

$11 \mathrm{~W}$ chwili sporządzania opisu drzwi łączące te lokalności były kotkami zabite (AGAD, GErel. 170: 545). 


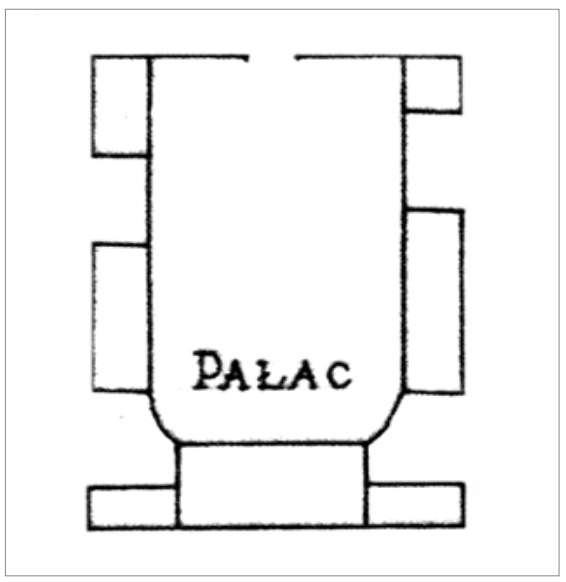

Ryc. 4. Schematyczny rzut pałacu w Gierałtach - wycinek mapy z I826 r., za: ZAP: U. I. I33; kopia za: Bergman i in. $1980,3:$ il. 4 .

Pomieszczenia mieszkalne dworu zaopatrzone były w powały i stropy zwykle wykonane $z$ tarcic, a także oświetlone oknami, z których dwa o sześciu dużych kwaterach oprawionych w ołów znajdowały się w izbie stołowej, jedno z podobnie oprawioną jedną kwaterą w pokoju średnim, a sześć bez kwater, ale za to z okiennicami w obu pokojach pasma lewego. Były też one ogrzewane piecami oraz służącymi również do oświetlania wnętrza kominkami. I tak piece występowały w obu pokojach pasma lewego (kaflowy zielony w pokoju od frontu, a określony jako takiż nowy w pokoju w trakcie tylnym), a kolejny piec (biaty kaflowy) znajdował się w izbie stołowej. W co najmniej dwóch z tych pomieszczeniach, tj. w pokoju leżącym w tylnym trakcie pasma lewego oraz w pokoju średnim, znajdowały się murowane kominki, kolejny zaś wymurowano w sieni. Inwentarz wymienia też komin murowany, w którym blacha żelazna w frontowym pokoju pasma lewego, a w izbie stołowej komin murowany dawny z blacha żelazna ${ }^{12}$, których charakter trudno jednoznacznie określić, bowiem w źródłach z XVII i XVIII w. nie raz spotyka się zamienne używanie określeń „komin” i „kominek” (Szewczyk 2009: 54) ${ }^{13}$. Wspomniane „blachy żelazne” mogły natomiast być zarówno żeliwnymi płytami mocowanymi do tylnej ściany otwartego kominka dla jej ochrony przed ogniem oraz dla odbijania i akumulacji ciepła (Kaminplatte), jak i - co jednak jest bardzo mało prawdopodobne - płytami (lub drzwiczkami) związanymi z popularnym już wówczas w Niderlandach, Francji, Anglii oraz południowych Niemczech ogrzewaniem kanałowym (Takenplatte) (Driesch 1990; Mróz 200I: 8). Możliwe jest też jednak, iż były to spełniające podobne funkcje zwykłe blachy

12 Również w należącym do dóbr kutnowskich folwarku w Raszewie w I710 r. w budynku do pomieszkania odnotowano zarówno komin murowany nad budynek wywiedziony, jak i [W iz] biepieckaflowy i komin murowany z blachażelazną oraz komin w alkierzu z blacha żelazną (AGAD, APR I53: 89).

13 Jak np. w położonych na Lubelszczyźnie Kaliszanach w inwentarzu z roku 1669 odnotowano zarówno kominek do świecenia, jak i to dwukrotnie przy piecu komin murowany dla światta z blachą (Gloger 1909: I10). Te drugie za kominki uznał Józef Stanisław Jamroz (1983: 153). 


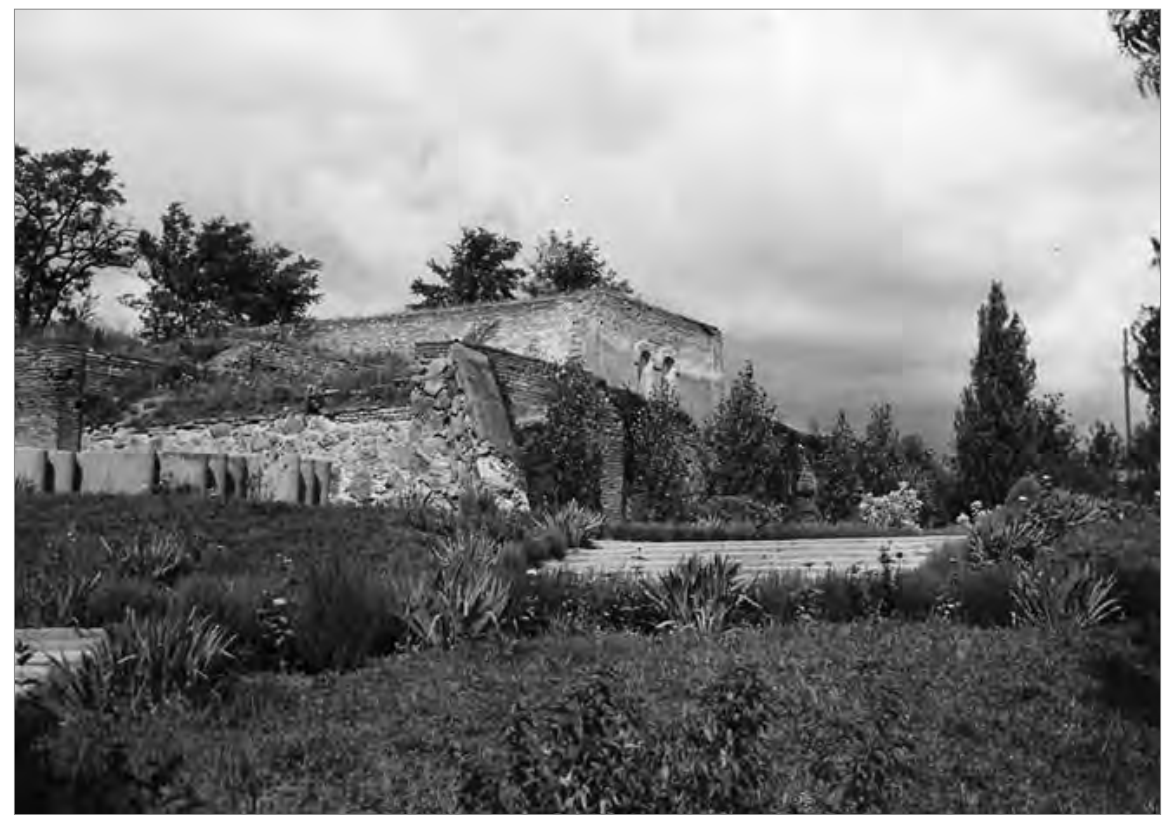

Ryc. 5. „Burgruine” (wł. ruina d. lodowni/browaru) w Kutnie, fot. A. Kiss, I940, Za: WBP-MJP, AO: FAO 5/47 PR.

żelazne, albo też takież blachy lub żeliwne płyty zamykające spotykane z rzadka w ścianach kominków czeluście pieców, czy też zasuwy odcinające wylot spalin kierowanych z pieca do komina (Tłoczek 1985: 123; Dąbrowska 1987: 159-160; Szewczyk 20II; 20I2). Sprawę komplikuje dodatkowo wzmianka, iż urządzenia grzewcze obu pokoi lewego pasma obsługuje dymnik $k^{14}$. To wszystko zaś powoduje, iż nie jesteśmy w stanie określić liczby kominów wywiedzionych ponad dach i odprowadzających dym z dworskich pieców i kominków. Wiemy natomiast, że znajdowało się tu dziesięć otworów drzwiowych (łącznie z prowadzącymi na zewnątrz i poddasze, a nie licząc zabitych i pozbawionych stolarki) zamykanych jednoskrzydłowymi drzwiami (z tych dwoje stare stolarską robotą rżnięto), z których prawie wszystkie były zawieszone na zawiasach i hakach żelaznych oraz zaopatrzone w zróżnicowane, żelazne zamknięcia (wrzeciądze, skoble, antaby $\mathrm{i}$ haczyki), a sporadycznie też w żelazne i drewniane klamki. Wejście wiodące na poddasze i może dalej do wyniesionych nad przyziemie altan zapewniały znajdujące się w sieni obite tarcicami schody (AGAD, Gırel. 170: 545; Kobierecki 20II: 190).

14 Pojawia się on też w dwu innych budynkach folwarcznych, zaś w XVII-wiecznych słownikach podawano, że jego synonimem jest zwrot Komin wywiedziony dla dymu (AGAD, GŁrel. 170: 545, 545v, 546; Cnapii 1621: 296; Szyrwid 1677: 8I). 
Po zinwentaryzowaniu dworu rewizor podążał na południe, opisując kolejne obiekty leżące po wschodniej stronie zespołu. Pierwszym z nich był budynek mieszczący browar oraz ozdownię i skupiający całą produkcję piwa pod jednym, krytym słomą dachem ${ }^{15}$. Ten pierwszy był miejscem jego warzenia, dlatego też znajdowały się w nim służące temu urządzenia i sprzęty, w tym przede wszystkim komin lepiony z gliny, kotlina stara z cegty, kociot miedziany stary. Dostęp światła dziennego zapewniało tu zamykane okiennicą okno. Natomiast pozbawiona okien ozdownia służyła najpewniej - jak to często miało miejsce również w innych zespołach folwarcznych - nie tylko suszeniu słodu, ale i wcześniejszemu roszczeniu ziarna. Jej wnętrze podzielone było na dwa dostępne z browaru poziomy. Dolny mieścił wymurowany z cegły piec ogrzewający powietrze i w ten sposób suszący rozłożone na górnym poziomie zroszczone zboże (AGAD, GŁrel. 170: 545; Klonder 1983: 47-53; Kobierecki 20II: 190; Pietrzak 2013: 73n).

Naprzeciwko browaru wznosiła sięprzed kilku lat zbudowana obora. Jej opis jest na tyle nieprecyzyjny, iż nie możemy jednoznacznie stwierdzić, czy pod pojęciem tym kryję się jeden podzielony na odmiennie użytkowane części budynek, czy też cały ich wygrodzony dylowaniem zespół. Wiemy jednak, iż obiekt ten nie był jeszcze w pełni ukończony, gdyż dach tylko w połowie pokryty był słomą, w połowie zaś zamocowano nań jedynie drewniane łaty. Wiemy też, iż prowadziły doń wrota wykonane z tarcic, zawieszone na biegunach i zaopatrzone w żelazną kunę. Mieściła się tu także kryta słomą wołownia z drzwiami na biegunach i niedokończoną (?) podłogą z dylów oraz siedem chlewów - wszystkie zaopatrzone w pozbawione zamknięć drzwi na biegunach (AGAD, GÆrel. 170: 545-545v; Kobierecki 20II: 190).

Kolejny obiekt, określony wpierw jako pobudynek, niżej zaś nazwany kuchennym, powstał $\mathrm{w}$ wyniku niedawno podjętej i jeszcze niezakończonej przebudowy oraz rozbudowy starszego budynku, którego jednym z pomieszczeń była piekarnia dawno wystawiona. Jak się wydaje, był to wydłużony, nowo pokryty słomą obiekt o trudnym do określenia, może w części - a nawet w całości - dwutraktowym rozkładzie pomieszczeń. Trudna do jednoznacznego określenia jest nawet ich aktualna i planowana liczba. W przebudowywanej, starszej jego partii lustrujący wymienił: gorzelnię pomieszczoną w izbie służącej dawniej jako piekarnia, izdebkę, komorę oraz jedną lub dwie sionki mieszczącą/mieszczące studnię ${ }^{16} \mathrm{i}$ kuchnię. Najpewniej też częścią tego pierwotnego budynku była również kolejna nieukończona jeszcze izdebka, przeznaczona dla piekarza. Na opisywanym przez rewizora etapie przebudowy tej partii budynku w sionce z kuchnią znajdował się stary komin, dołem sztagowy, górą zaś murowany, oraz dymnik wymurowany z cegty obsługujący

15 Proces produkcji piwa w przeszłości dokładniej opisuje m.in. Andrzej Klonder (1983: 46-60).

16 Była ona obita tarcicami i ocembrowana stara dębina (AGAD, GŁrel. 170: 545v). 


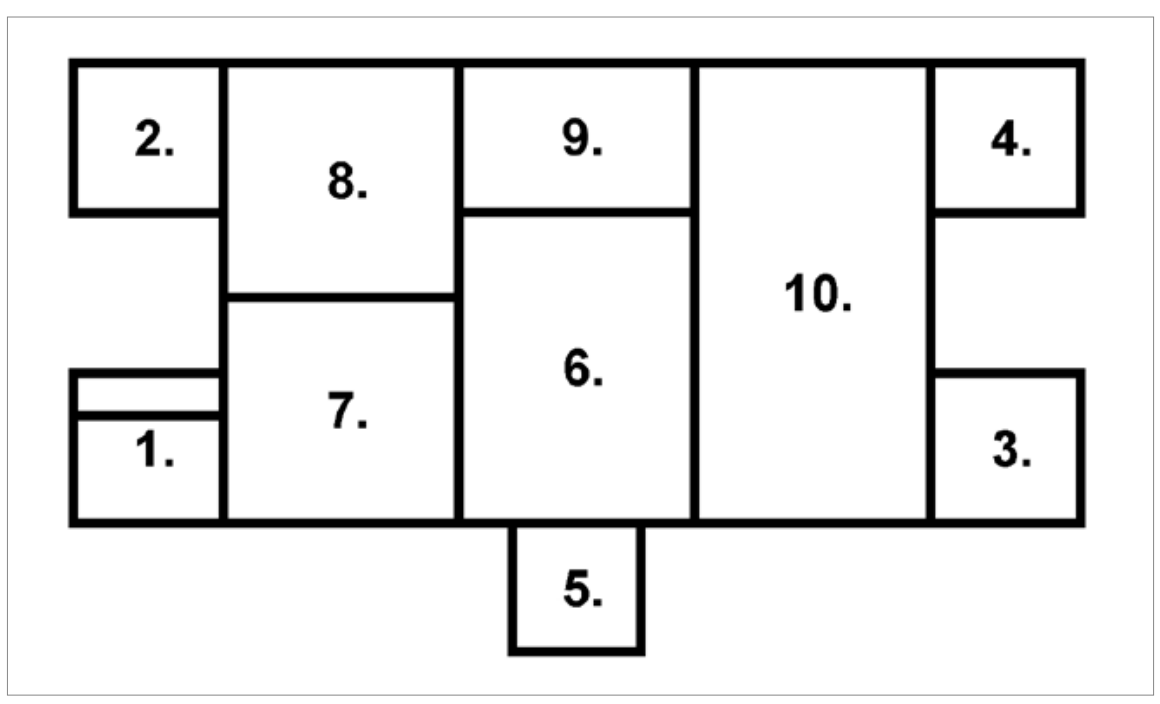

Ryc. 6. Rekonstrukcja najbardziej prawdopodobnego układu pomieszczeń dworu w Kutnie w 1695 r. rys. J. Pietrzak.

I. alkierz /secretum i poboczna komorkal; 2. alkierz laltanka spustoszata/; 3. alkierz laltanka dawna teraz sionkal; 4. alkierz /pokoj spustoszaty nad którym altanka spustoszata/; 5. ganek z altanką na górze; 6. sień; 7. pokój w trakcie frontowym; 8. pokój w trakcie tylnym; 9. pokój średni; Io. izba stołowa.

urządzenia grzewcze pomieszczone w obu izdebkach, tj. w jednejpiec kaflowy prosty oraz kominek, w drugiej (dla piekarza) piec [piekarniany /?/ - dop. JP] wymurowany, który wychodzi pod kuchnię. Były one ustawione chyba przy wspólnej dla obu izdebek, oblepionej gliną ścianie. W pierwszej z nich znajdowało się też jedyne w tej części budynku okno (dwukwaterowe) szklone w ołów, w trzech następnych oknach tej partii obiektu szkło oprawiono w drewno ${ }^{17}$, a ostatnie było bez szkła.

Z kolei w nieukończonej, dostawionej części budynku kuchennego miejsce znalazły: dwie izby, trzy komory do schowania ${ }^{18}$. Pomieszczenia te zaopatrzone były w okna zamykane okiennicami, z tym, iż w oknach izdebnych - w łącznej liczbie pięciu - było to ich jedyne zabezpieczenie, podczas gdy okna komór - trzy, po jednym w każdej z nich - były zaopatrzone również w po dwie szklone w ołów

17 Przy czym w jednym z dwu dwukwaterowych okien gorzelni jedną z kwater deszczkami zabito (AGAD, Gerel. 170: 545v).

18 Według zeznań Jana Wittana z 1695 r. do starej Kuchni przybudowano budynek nowy z dylów w kostkę (AGAD, APR I53: III). 
kwatery. Żadne z nich nie posiadało natomiast jeszcze (?) urządzeń grzewczych. Za to w ich sąsiedztwie znajdowało się piecowisko, to jest fundament zatożony $i$ kominy dwa także zaczęte, ale nie dokończone.

Niedokończone były również prace we wnętrzach obu części budynku. Co prawda w starej jego części większość otworów drzwiowych była już zaopatrzona w skrzydła drzwiowe (tak stare, jak i nowe) zawieszone na hakach żelaznych i zabezpieczane głównie takimiż zamknięciami zestawianymi w dość zróżnicowany sposób (skoble, wrzeciądze, haczyki), ale na przejściu z izby dla piekarza do partii nowo wznoszonej w ościeżnicy brakowało jeszcze drzwi. Był to chyba jednak jedyny taki brak w postawionych tu ścianach. Brakowało natomiast niektórych planowanych podłóg i pował. Z kolei w większości pomieszczeń części starej zachowano stare i założono nowe powały z tarcic. Nie było jej jedynie w gorzelni, gdzie jednak położono jedyną w tej partii budynku podłogę z tarcic (AGAD, GŁrel. 170: 545v-546; Kobierecki 2011: 190).

Następny wspomniany przez rewizora obiekt miał zupełnie inny charakter od wszystkich innych zabudowań wznoszących się w obrębie ogrodzenia folwarcznego. Znajdował się on naprzeciwko budynku folwarcznego, a określony został jako $z a-$ mek stary na kopcu murowany pusty, w oknach niektórych kraty sa żelazne (AGAD, GŁrel. 170: 546). Enigmatyczność tego opisu nie upoważnia do wyciągania zeń jakichś szerszych wniosków, dlatego też ograniczymy się tu do pow tórzenia sugestii Leszka Kajzera, iż obiekt ten nie byt zamkiem $w$ dzisiejszym rozumieniu tego stowa, a raczej murowanym dworem obronnym wzniesionym na kopcu ziemnym, otoczonym fosa (?), powstał zaś z inicjatywy rodziny Kucieńskich najwcześniej w okresie życia Andrzeja wojewody rawskiego († po I530 r.) lub jego syna Stanistawa, dworzanina królewskiego a potem także wojewody rawskiego († I542), najpóźniej zaśw czasach ostatniego wybitnego Kucieńskiego, Stanistawa, syna Wojciecha, podkomorzego gostynińskiego († 1579) (Kajzer 1998: 2I-22; zob. też 1980: 227; 1987: 455). Ze swojej strony możemy jedynie dodać, iż ze sporą dozą prawdopodobieństwa można przyjąć, iż kopiec, na którym go wzniesiono, jest tożsamy z obiektem - właściwie jego częścią - określonym na początku XVI w. jako curia seu fortalicio, który, jak już pisaliśmy wyżej, wojewoda rawski Andrzej († I503) przed śmiercią zapisał jednemu ze swych synów - a los wskazał młodszego z nich Andrzeja (od Isı r. również wojewodę rawskiego - † po I530), jednego z wymienionych przez L. Kajzera - w zamieszczonym wyżej cytacie - potencjalnych inicjatorów budowy murowanego dworu (AGAD, G£rel. 170: 546; Kajzer 1987: 455; 1998: 2I-22). Należy też stwierdzić, iż naszym zdaniem badacz ten miał rację identyfikując w pracy z 1987 r. omawiany tu zamek starym na kopcu z murowanym budynkiem wzniesionym na planie krótkiego prostokąta o boku ponad is $m$, największym z trzech oznaczonych na planie miasta z 1826 r. numerem hipotecznym 248 (ZAP: U. II. 75; 
Kajzer 1987: $\left.453-454^{19}\right)$. Sądzimy też, iż jego relikty mogą nadal tkwić w zabudowaniach wznoszących się obecnie na działce nr 532/3 (Kutno, obręb geodezyjny Śródmieście). Domniemanie to wymaga jednak weryfikacji w trakcie badań archeologiczno-architektonicznych, choć na podwórzu tej posesji w trakcie badań przeprowadzonych w 2000 r. natrafiono już na „dworski” materiał zabytkowy (m.in. kafle pochodzące z „pańskiego” pieca) (Pietrzak 2002: 62).

Na południe, jak chce rewizor, od kopca z „zamkiem” wznosił się kolejny obiekt, znów nazwany wpierw tylko pobudynkiem, później zaś określony mianem budynku folwarcznego. I właśnie użycie tego epitetu pozwala widzieć w nim obiekt łączący w sobie funkcje mieszkalne i gospodarcze (choć w tym wypadku najpewniej ze zdecydowaną przewagą tych pierwszych), o jakim pod koniec XVII w. pisał Jan Krzysztof Haur, iż ma być domem wygody gospodarstwa, domem pokoju, albo przytuleniem i odpoczynkiem po pracach gospodarskiej czeladzi. W Kutnie był to budynek nowo nakryty stoma, w którego wnętrzu znajdowało się pięć lokalności powstałych tak jak w pobudynku kuchennym w trakcie dwu osobnych przedsięwzięć budowlanych. W czasie pierwszego z nich zbudowano sień z niewydzieloną przestrzennie kuchnią, sąsiadującą z nią izbę i ustawioną najpewniej przy jej tylnej ścianie komorą. Był więc to budynek jednotrakowy, który można zaliczyć do grupy popularnych na wsi polskiej przez długi czas tzw. domów centralnych. W następnym etapie do drugiej z ścian sieni dostawiono dwie kolejne lokalności, tj. izbę (izba nowa, niedokończona $[\mathrm{z}]$ dylów ciosanych w stupy - a więc o sumikowo-łątkowej konstrukcji ścian /uw. JP/) oraz komorę, utrzymując jednotraktowy plan budynku i nadając mu formę określaną przez badaczy wiejskiego budownictwa mieszkalnego domem szerokofrontowym, wielownętrznym. Rozbudowa ta, a także prowadzone przy tej okazji prace w starej części, w chwili spisywania inwentarza nie były jeszcze ukończone, choć, jak się wydaje, brakowało już tylko drzwi wejściowych do sieni, ogniska (tj. paleniska) w kuchni oraz pieca mającego ogrzewać nową izbę. Budynek wyposażony był już jednak w większość drzwi - po części nowych, po części starych - zawieszonych na zawiasach i hakach żelaznych i w większości zapatrzonych w wykonane z takiegoż metalu zamknięcia (wrzeciądze, skoble i haczyki). Zabezpieczono też wszystkie otwory okienne, szkląc je w ołów, tak w obu izbach (po dwa czterokwaterowe okna, przy czym w partii starszej zaopatrzono je również w okiennice), jak i komorach (po jednym dwukwaterowym oknie). Co do wyposażenia wnętrz, to w sieni i izbie leżących w starej części budynku nie było podłóg i pował, były one natomiast założone w obu dostawionych lokalnościach (gdzie wykonano je z tarcic) oraz starej komorze (z dyli). Dalej zaś: w położonej w sieni kuchni (gdzie, jak wspomniano, brakowało ogniska) znajdowały się dwa murowane

19 W artykule z 1998 r. od stwierdzenia tego jednak nieco się zdystansowal (Kajzer 1998: 17-21). 
kominki oraz dymnik glina oblepiony, czyli najpewniej komin sztagowy, w izbie starejpiec kaflowy prosty, a w izbie nowej kominek od spodu murowany i fundament na [brakujący jeszcze - dop. JP] piec, a spodem do pieczenia chleba (AGAD, GŁrel. 170: 546; Haur 1675: 22; Czajkowski 20II: 7I-IOI, I49-162; Kobierecki 20II: 190).

Dalej - jednak w pobliżu opisanego ostatnio budynku - wznosił się nienazwany i nieopisany bliżej budynek nowo wzniesiony, ale nieukończony jeszcze od południa, w części środkowej źle (lub nie w pełni) poszyte, zaś od północy mieszczące stajnię i stajenkę, których naprawy potrzebowało słomiane poszycie dachu. Z kolei na północ od nich, w obrębie wygrodzonego żerdziami gumna, wokół wewnętrznego, gumiennego podwórza, ustawiona była stara, podniszczona, poszyta słomą szopa oraz dwie stodoły - mieszczące po dwa klepiska i zapewne po trzy sąsieki - których dachy wspierały się na sosnowych słupach. Z jedną z nich, określoną w przekazie jako nowa, związane były dwa małe spiklerzyki z podłogami i pułapami wykonanymi z dyli. Wrota klepisk zawieszono na biegunach i kunach żelaznych, drzwiczki spichlerzyków tylko na biegunach. Do ich zamknięcia służyły żelazne wrzeciądze i skoble (AGAD, GErel. 170: 546).

Jeszcze dalej na północ - może już w pobliżu traktu poznańskiego - rewizor opisał kolejny już budynek o pięciu lokalnościach rozłożonych w trzech w części dwutraktowych pasmach, tym razem niedawno wyremontowany, a przy tym także oblepiony gliną. W jego paśmie środkowym od frontu zlokalizowana była sionka, zaś w trakcie tylnym kuchnia. Podobnie zapewne rozmieszczone były izba i komora zajmujące jedno z pasm bocznych, podczas gdy drugie z pasm w całości wypełniała druga izba. Ostatnią przestrzenią użytkową tego budynku było poddasze określone w przekazie jako schowanie górne, do którego dostęp umożliwiały schody znajdujące się w sieni. O ile poddasze to pełniło oczywiście funkcję gospodarczo-magazynową, o tyle cały budynek był bez wątpienia przeznaczony znów - tak jak jego wyżej opisany budynek folwarkowy - przede wszystkim do mieszkania. W tym wypadku jednak standard jego wykończenia i wyposażenie sugerują, iż służył on nie czeladzi dworskiej, a raczej osobie/osobom zdecydowanie wyżej postawionym ${ }^{20}$. I tak - w tym, jak wspomniano, niedawno odnowionym domu - obie izby wyposażone były w piece (kaflowy prosty i potrzebujący reperacji), a przynajmniej jedna również i w kominek. Ponadto ich powały i podłogi wykonane zostały z tarcic, w komorze zaś w tym samym celu użyto dyli. Wreszcie wszystkie drzwi (w większości nowe) zawieszone zostały na zawiasach i hakach

20 Możliwe, iż to o nim wspomina kontrakt zawarty w 1696 r. pomiędzy kasztelanem czernichowskim Janem Proskim działającym w imieniu Anny Zamoyskiej a Kazimierzem Ubyszem, podając, że pierwszy z nich upuszcza JMci panu Ubyszowi to mieszkanie, w którym teraz JM Pan Wittan [dzierżawca dóbr w roku poprzednim - uwaga JP za: Kobierecki 20II: 188] mieszka (AGAD, APR 153: 3, to samo k. 7). 

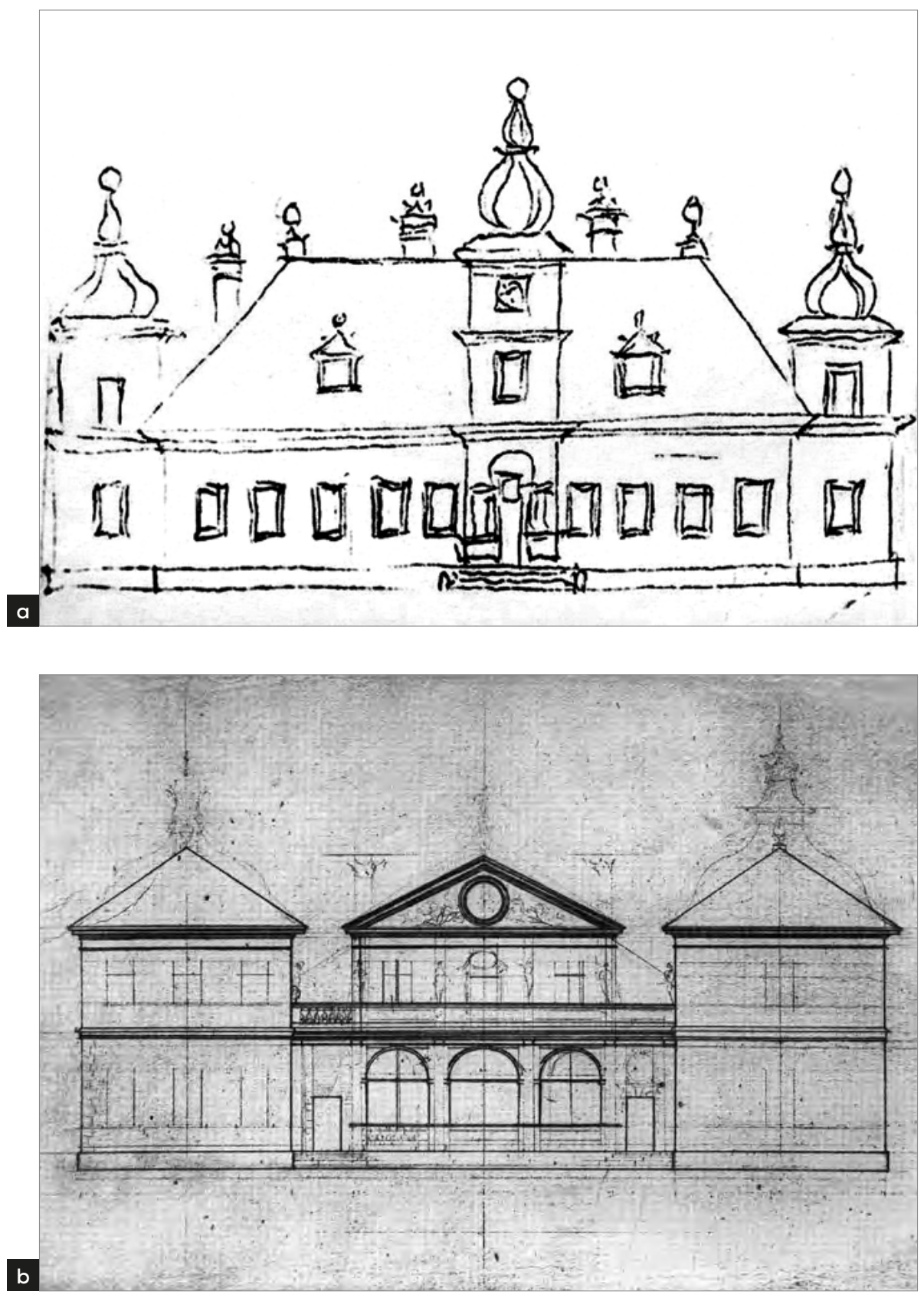

Ryc. 7. Projekty drewnianych dworów: a. Opalińskiego, rys. G.B. Gisleni, za: SKD, KK: Ca 67/48v; b. A.T. 472, rys. Tylman z Gameren, za: Mossakowski 20I2: il. 287. 
żelaznych, a także zaopatrzone w żelazne zamknięcia (wrzeciądze, skoble i haczyki). Podobnie zamknięte było też wejście wiodące na poddasze. $Z$ kolei pięć tamtejszych okien (po dwa czterokwaterowe w izbach i jedno dwukwaterowe w komorze) posiadało kwatery oprawione w ołów (AGAD, GŁrel. 170: 546-546v; Kobierecki 20II: 190).

Kilka kolejnych obiektów stanowiących własność dworu wznosiło się już poza obrębem podwórza folwarcznego, przy czym część z nich - jak się wydaje - nie była odeń zbyt oddalona, inne zaś funkcjonowały już zapewne w znacznie większej odległości. Do pierwszych należał drugi z dworskich browarów, który, choć określony jako dawno wybudowany, nadal był zaopatrzony w sprzęty (po części stare, po części nowe) wykorzystywane przy produkcji piwa, zarazem jednak nie wiemy nic o koniecznych przy tych działaniach urządzeniach grzewczych. Blisko zabudowań dworskich powstał również nowo wybudowany młyn koński z dachem pokrytym gontem, a więc młyn napędzany dzięki wykorzystaniu siły zwierząt, czy to z zastosowaniem ciągniętego przez nie kieratu, czy też koła deptakowego, a niedaleko tego mtyna w ciągu ostatnich dwu lat przed spisaniem inwentarza zbudowano cegielnię z murowanym $\mathrm{z}$ cegły piecem, nad którym wykonano pobite tarcicami zadaszenie (AGAD, APR I53: III; AGAD, G£rel. 170: 546v; Kobierecki 20II: 190; zob. też np. Osiński 1777: 347-349, tabl. 6: fig. 128-130; Pietrzak 2013). Z kolei obiektem dalej położonym był stary, jednokołowy młyn wodny, który zapewne identyfikować można z młynem zwanym w XIX w. Dybowskim (Dubowskim), usytuowanym na zachód od miasta przy założonym na rzece Ochni stawie. Natomiast gościniec, gdzie Łapiński mieszka trzeba identyfikować z jedynym takim istniejącym podówczas w Kutnie obiektem - drugi spłonął między 1689 a 1695 r. ${ }^{21}$ - w którym działający w imieniu Anny Zamoyskiej kasztelan czernichowski Jan Proski reperowat stanie ${ }^{22}$, izdebkę i komoręprzybudowat i zgruntu poszyt, a który wznosił się w, niestety, bliżej nam nieznanym miejscu $w$ mieście. Możemy jedynie suponować, iż mógł on funkcjonować w rejonie dzisiejszego Placu Wolności (czyli dawnego Starego Rynku), gdzie dziewiętnastowieczne źródła odnotowują obecność austerii (AGAD, APR I53: III-II6; AGAD, ZGSA: AK I57, ark. [VIII, IX]; SBB, PK, Kart N I443I: XXXVIII; ZAP: U. II. 75; AGAD, GErel. 170: 546v; Kobierecki 20II: 190).

21 Drugi kutnowski gościniec stał na Żydowskim Rynku i jednak, według różnych poczynionych w 1695 r. zeznań, bądź to per incuriam Gospodarza [...] zgorzat, zgorzat bez nieostrożność Żyda arendarza, bądź też zgorzat casu fortictu, czy wreszcie gdy żotnierze stali zgorzat, co nastąpiło, jak się wydaje, w czasie, gdy miasto było już w posiadaniu Anny Zamoyskiej, a który nie został jeszcze odbudowany (AGAD, APR I53: III, II3, II 4).

22 Informację tę podaje w swych zeznaniach z $1695 \mathrm{r}$. J. Wittan, zaś w sporządzonym w tym samym czasie inwentarzu zapisano, iż stajnia ta była nowo zbudowana (AGAD, APR I53: III; AGAD, GErel. 170: 546v; por. Kobierecki 20II: 190). 
Przynajmniej część działań, które pozwoliły użyć rewizorowi w inwentarzu określeń wskazujących na niedawne powstanie czy też remont budynków, poczyniono w czasie, gdy gospodarowali tu pełnomocnicy Anny Zamoyskiej. Tym samym można sądzić, iż podejmowano je zaś bądź to z jej inicjatywy, bądź też przynajmniej za jej pozwoleniem lub zgodą. O ich efektach mówiąświadkowie w przywołanych już, spisanych w 1695 r. zeznaniach, informując, iż Pani Podskarbina nic w budynkach dworskich niezdesolowata i owszem reparowata i wspominające m.in. o pracach remontowych przeprowadzonych w dworze, wystawieniu obór nowych w miejsce starych, spalonych, remoncie i powiększeniu starego budynku kuchni (piekarni), budowie noweji remoncie starej stodoły, wzniesieniu budynku nadkopcem, a także kilku chałup ratajskich oraz młyna końskiego i cegielni, dalej zaś remoncie oraz rozbudowie gościńca w mieście (AGAD, APR I53: III-116; por. Bergman i in. 1980, I: 23-24, 29; Kajzer 1987: 452; 1998: 15; Kita 201 rb: 271; Kobierecki 2011: 192, 199).

Również i po 1695 r. dobra kutnowskie notorycznie oddawane były w dzierżawę, a także w zastaw. Sam fakt czasowej zmiany użytkownika dóbr w tym trybie nie wyklucza oczywiście możliwości podejmowania działań remontowych i budowlanych, gdyż utrzymanie majętności w dobrym - właściwie niezmienionym - stanie i w takim zwrócenie jej właścicielowi było obowiązkiem tak dzierżawcy, jak i zastawnika. Spełnienie tego warunku dokumentowano w inwentarzach spisywanych przy oddawaniu i odbiorze dóbr, $\mathrm{z}$ których pierwszy był w zasadzie integralną częścią kontraktu. Dzierżawa nie wykluczała jednak możliwości podjęcia także prac większych niż naprawcze, mogły być one wręcz nakazane kontraktem, a stanowiąc jego integralną część, znacząco wpływać na gotówkową cenę transakcji. Ponieważ jednak w interesie czasowego dysponenta nieruchomości nie leżało podejmowanie inwestycji w niestanowiący jego własności majątek trwały, zazwyczaj dążył on do ich minimalizacji. W efekcie m.in. nie dbał o konserwację budynków (Baranowski I964: 106). Zapewne to właśnie dlatego zaledwie w is lat później w jednym z kolejnych kontraktów pojawia się zapis informujący nas, iż budynki są nadruinowane i restauracji potrzebuja i ustalający,

że cokolwiek $\mathrm{P}[\mathrm{an}]$ Pułkownik ${ }^{23}$ de nova radice po[stawi] lub starych poprawi to wszystko za podaniem rzetelnej e[xpensy] na nie, przy expiracji kontraktu za mediacją przyjacielsk[ą] [przy]wrócone na być. Snopkiem zaś, słupem, gliną, płotem

23 Jan Michał Sołłohub, w chwili zawierania kontraktu cześnik żmudzki, pułkownik kawalerii Wielkiego Księstwa Litewskiego oraz tenutariusz położonych pomiędzy Kutnem a Gostyninem dóbr strzeleckich (od I713), później podkomorzy gostyniński, łowczy wielki litewski, podskarbi wielki litewski i wojewoda brzesko litewski, m.in. tenutariusz znów nieodległych od Kutna Sannik (od 1720) i właściciel pobliskiego Oporowa (od 1725) (Niesiecki 1743: 164; Romaniuk 200r). 
oblig[uje] się Jegom[ości] poprawić tak koło dworu jako i Ratajów. Restaurac[ja] [zaś] młyna i grobli jeżeliby niezbyt wielkiej potrzebowała expensy tedy cokolwiek na to będzie łożyl, to Jchm[o]ści P [aństwo] Starostowie Bolemowscy ${ }^{24}$ powrócić będą powinni (AGAD, APR I53: 98 /zob. też: 102/).

Niestety, nie wiemy, jak potoczyły się dalsze losy tak dworu, jak i zabudowań folwarcznych w Kutnie. Brak jest też podstaw dla próby określenia czasu likwidacji tego założenia. Możliwe jednak, iż miało to związek z jednej strony z wzniesieniem w drugiej połowie XVIII lub na początku XIX w. nowego murowanego dworu zachowanego do dziś (choć dość mocno przebudowanego), zlokalizowanego w pobliskich Gierałtach, $\mathrm{z}$ drugiej zaś powstaniem na północ od miasta nowych zabudowań folwarcznych. Wydaje się też, iż już w pierwszej ćwierci XIX w. teren ten służył innym celom. Zapewne tak jak i później funkcjonował tu dominialny browar, uzupełniony następnie o gorzelnię i rozbudowany aż do wybuchu II wojny światowej (ZAP: U. II. 75; Kita 20IIc: 349-353).

\section{Bibliografia}

\section{Źródła archiwalne}

AGAD, APR (Archiwum Główne Akt Dawnych, Archiwum Potockich z Radzymina) sygn. I53: Akta procesowe E. Potockiego z Zamoyskimi o pretensje jego do dóbr Kutno, będących w posiadaniu matki z pierwszego małżeństwa, Marcinowej Zamoyskiej.

AGAD, Gærel. (Archiwum Główne Akt Dawnych, Księgi grodzkie łęczyckie, Liber relationum)

sygn. 170: Inwentarz Osady Miasta Kutna. Powinności ich. Także Prowentów wszelkich, tudziesz Budinków Dworskich. Spisany sub Tempus condescensionis Officiorum d[ie] 28 septembris $\mathrm{A}[\mathrm{nn}] \mathrm{o} 1695$.

AGAD, MK (Archiwum Główne Akt Dawnych, Metryka Koronna)

sygn. 2I; 64, 293.

AGAD, zGSA (Archiwum Główne Akt Dawnych, Zbiór geograficzny Stanisława Augusta) sygn. AK I57: Itineraire topographique de la route de Varsovie par Łowicz à Kalisz, avec des renseignements statistiques, reconnu et dressé dans le courant du 2d Trimestre 1825. par

24 Marcin Leopold Zamoyski (starosta bolimowski od 1687) i Konstancja z Druckich Podbereskich Zamoyska (dożywocie wspólne od 1713) (Kobierecki 2011: I82; Chłapowski 2017: 315). 
les Officiers de l'Etat Major Géneràl de l'Armée Royale Polonaise partie du Quartie Maitrât [Skala I : 84000$]$.

SKD, KK (Staatliche Kunstsammlungen Dresden, Kupferstich-Kabinett)

$\mathrm{nr}$ inw. Ca 67/48v, za: https://skd-online-collection.skd.museum/Details/Index/II22989

[20 IX 202I], domena publiczna.

SSB, PK (Staatsbibliothek zu Berlin, Preussischer Kulturbesitz), sygn. Kart N I443I, Bl. xxxviII: D. Gilly [Südpreussen] 1793-1796 [Skala: ca. I : 50 o00].

wвр-мjр, Aо (Wojewódzka Biblioteka Publiczna im. Marszałka Józefa Piłsudskiego w Łodzi, Archiv Ostlandbild)

sygn. FAO 5/47 PR: Kiss A. Kutno. Burgruine, 1940, https://bc.wbp.lodz.pl/dlibra/publication/100634/edition/96150/content [24 IX 202I], domena publiczna.

ZAP (Zakład Architektury Polskiej Wydziału Architektury Politechniki Warszawskiej) sygn. U. I. 133: Kutno - plan z r. 1826 - przedłużenie ul. Zamkowej.

sygn. U. II. 75: Plan Miasta Prywatnego Kutna Jaśnie Wielmożnego Gliszczyńskiego Kasztelana Położonego w Powiecie Orłowskim, Obwodzie Gostyńskim Woiewództwie Mazowieckiem. Ułożony w Miesiącu Wrześniu i826. Roku przez Fr. Frösewitz, Geomter[a]. Rzą[dowy] [Skala: ca. I : 2500].

\section{Opracowania}

Baranowski B. (1964), Zmiany w stosunkach folwarczno-pańszczyźnianych w drugiej potowie XVIII w., [w:] Zarys historii gospodarstwa wiejskiego w Polsce, t. II, Państwowe Wydawnictwo Rolnicze i Leśne, Warszawa, s. 88-I15.

Bergman E. (1995), Historia budowy miasta Bieżunia, „Bieżuńskie Zeszyty Historyczne", 5, S. I5-44.

Bergman E., Barbasiewicz M., Jernajczyk J. (1980), Kutno. Studium historyczno-urbanistyczne opracowane na zlecenie Wojewódzkiego Konserwatora Zabytków w Płocku, cz. I-3, Warszawa (maszynopis PP. PKZ w Warszawie, kopia w zbiorach Muzeum Regionalnego w Kutnie).

Chłapowski K. (2017), Starostowie niegrodowi w Koronie 1565-1795. (Materiaty źródtowe), Wydawnictwo DiG, Warszawa-Bellerive-sur-Allier.

Ciekliński Z. (1954), [rec.] Katalog zabytków sztuki w Polsce. Tom II. Województwo tódzkie, pod redakcja Jerzego Z. Eozińskiego, Państwowy Instytut Sztuki, Warszawa I953, „Ochrona Zabytków”, 7.4, s. 278-286.

Cnapii [Knapiusz] G. (1621), Thesaurus Polono Latino Graecus, seu Promptuarium linguae Latinae et Graecae, Polonorum usui accommodatum. Quid in eo praestitum sit, in Proaemio leges. Hic illud affirmare licet: In hoc Opus congesta esse, quaecunque ad Latinarum \& Graecarum simplicium vocum nomenclaturam, \& ad coniunctarum phrasim pertinentia, continent Thesauri Graeci \& Latini, item Calepini, Nizolii, Lexica, Dictionaria, Nomenclatores, libri denique Synonymorum, Copiae verborum, ac Phrasium, Graeci \& Latini. Additae praeterea prope mille voces Latinae, quibus Thesauri \& Calepini carent, \& totidem fere, quae in eisdem vitiosae sunt, correctae. Deprompta haec ex bonis Scriptoribus, eorumque exemplis, ubi erat opus illustrata: 
additis etiam interpretationibus obscuriorum locorum, \& multimoda eruditione ex Philologorum \& Criticorum libris, Cracoviae.

Czajkowski J. (2011), Dom drewniany w Polsce. Tysiąc lat historii, Zakład Wydawniczy „Nomos”, Kraków.

Czekalska K. (1999), Zarys historyczny i analiza kompozycyjna Parku im. Romualda Traugutta w Kutnie, „Kutnowskie Zeszyty Regionalne”, 3, s. I29-I44.

Dąbrowska M. (1987), Kafle i piece kaflowe w Polsce do końca XVIII wieku, Zakład Narodowy im. Ossolińskich, Wrocław-Warszawa-Kraków-Gdańsk-Łódź.

Driesch K.von den (1990), Handbuch der Ofen-, Kamin-und Takenplatten im Rheinland, Rheinland-Verlag, Köln.

Gąsiorowski A. (1971), Kucieński Mikotaj h. Ogończyk (zm. I493), [w:] Polski stownik biograficzny, t. XVI, Zakład Narodowy im. Ossolińskich, Wrocław-Warszawa-Kraków-Gdańsk, s. 63-65.

Gloger Z. (1909), Budownictwo drzewne i wyroby z drzewa w dawnej Polsce, t. II, [b.w.], Warszawa.

Haur J.K.(1675), Oekonomika ziemianska generalna Punktámi Pártikulárnemi, Interrogatoryámi Gospodárskiemi, Praktyka Mieśięczna, Modelluszámi abo Tabutámi Arithmetycznemi obiaśniona. Pánom Dźiedzicznym, Arendarzom, Oekonomom, Attendętom, Urzędnikom, Pisárzom Prowentowym y wszystkim wpospolitości Dobr żiemskich Dozorcom pozyteczna y potrzebna, Kraków.

Hilchen H. (1912), Historya drogi żelaznej warszawsko-wiedeńskiej (I835-I848-I898). Przyczynek do dziejów kolejnictwa w Królestwie Polskim, Gebethner i Wolff, Warszawa.

Jamroz J.S. (1983), Mieszczańska kamienica krakowska, wiek XIII-XV, Wydawnictwo Literackie, Kraków-Wrocław.

Januszczak M.I.(2007), Park im. Wiosny Ludów - studium historyczno-przyrodnicze, „Kutnowskie Zeszyty Regionalne”, II, s. 471-488.

Jaroszewski T.S. (1966), O dwóch grupach polskich rezydencji wiejskich w drugiej potowie XVIII wieku. Ze studiów nad problematyka recepcji Palladia w Polsce, „Kwartalnik Architektury i Urbanistyki", II.2, s. 167-I9I.

Jaroszewski T.S. (1968), Ze studiów nad problematyką recepcji Palladia w Polsce w drugiej potowie XVIII wieku, [w:] Klasycyzm. Studia nad sztuka polska XVIII i XIX wieku. Materiaty Sesji Stowarzyszenia Historyków Sztuki, Poznań, październik Ig65, Zakład Narodowy im. Ossolińskich, Wrocław-Warszawa-Kraków, s. 133-188.

Józefecki J. (2002), Akta Komisji Rządowej Spraw Wewnętrznych w sprawie wykupu dochodów Dominalnych miasta Kutna w latach 1859-1867, „Kutnowskie Zeszyty Regionalne", 6, s. 337-356.

Kajzer L. (1980), Studia nad świeckim budownictwem obronnym województwa tęczyckiego w XIII-XVII wieku, „Acta Universitatis Lodziensis. Folia Archaeologica”, I.

Kajzer L. (1987), Uwagi o zamku w Kutnie i jego przemianach, „Kwartalnik Historii Kultury Materialnej", 35.3, s. 449-463.

Kajzer L. (1998), Uwagi o zamku w Kutnie, „Kutnowskie Zeszyty Regionalne”, 2, s. 9-36.

Kajzer L. (2010), Dwory w Polsce od średniowiecza do wspótczesności, Wydawnictwo DiG, Warszawa. 
Kin-Rzymkowska G. (2011), Rozwój przestrzenny miasta, urbanistyka i architektura, zabytki, [w:] J. Szymczak (red.), Kutno poprzez wieki, t. II, Prezydent Miasta Kutno, Miejska i Powiatowa Biblioteka Publiczna im. Stefana Żeromskiego, Polskie Towarzystwo Historyczne. Oddział w Łodzi, Kutno-Łódź, s. 437-49o.

Kita J. (2011a) Wtaściciele miasta i podmiejskich dóbr ziemskich, [w:] J. Szymczak (red.), Kutno poprzez wieki, t. I, Prezydent Miasta Kutno, Miejska i Powiatowa Biblioteka Publiczna im. Stefana Żeromskiego, Polskie Towarzystwo Historyczne. Oddział w Łodzi, Kutno-Łódź, s. 235-250.

Kita J. (2oIrb), Przestrzeń i infrastruktura miejska, [w:] J. Szymczak (red.), Kutno poprzez wieki, t. I, Prezydent Miasta Kutno, Miejska i Powiatowa Biblioteka Publiczna im. Stefana Żeromskiego, Polskie Towarzystwo Historyczne. Oddział w Łodzi, Kutno-Łódź, s. 25I-278.

Kita J.(20IIc), Życie gospodarcze, [w:] J. Szymczak (red.), Kutno poprzez wieki, t. I, Prezydent Miasta Kutno, Miejska i Powiatowa Biblioteka Publiczna im. Stefana Żeromskiego, Polskie Towarzystwo Historyczne. Oddział w Łodzi, Kutno-Łódź, s. 34I-363.

Klonder A. (1983), Browarnictwo w Prusach Królewskich (2. potowa XVI-XVII w.), Zakład Narodowy im. Ossolińskich, Wrocław-Warszawa-Kraków-Gdańsk-Łódź.

Kobierecki M. (20II), Dzieje Kutna i okolicznych wsi w XVII i XVIII wieku, [w:] J. Szymczak (red.), Kutno poprzez wieki, t. I, Prezydent Miasta Kutno, Miejska i Powiatowa Biblioteka Publiczna im. Stefana Żeromskiego, Polskie Towarzystwo Historyczne. Oddział w Łodzi, Kutno-Łódź, s. 177-218.

Kowalczyk J. (1959), Architekci Zamoyskich w XVIII wieku, „Kwartalnik Architektury i Urbanistyki”, 4.3-4, s. 21I-234.

Kowalczyk J. (2003), Zainteresowania i dziatalność architektoniczna ordynatów Zamoyskich w XVIII wieku, [w:] R. Maliszewska (oprac.), Ziemiaństwo na Lubelszczyźnie materiaty II sesji naukowej zorganizowanej w Muzeum Zamoyskich w Koztówce, 22-24 maja 2002, Muzeum Zamoyskich, Kozłówka, s. 87-III.

Kurzątkowska A. (1963), Barokowy zespól patacowy w Eabuniach koto Zamościa, „Studia i Materiały Lubelskie", I, S. 20I-220.

Latos A. (2002), Budowa drogi żelaznej warszawsko-bydgoskiej, „Kutnowskie Zeszyty Regionalne", 6, s. 357-364.

Latos A. (2015), Prace rewaloryzacyjne w zabytkowym Parku im. Wiosny Ludów w Kutnie, Towarzystwo Przyjaciół Ziemi Kutnowskiej, Kutno.

Lesiak H. (2007), Szlakiem dworów regionu kutnowskiego, Agencja Rozwoju Regionu Kutnowskiego SA, Kutno.

Majewska G. (1984), Architektura na tle rozwoju przestrzennego miasta, [w:] R. Rosin (red.), Kutno. Dzieje miasta, Państwowe Wydawnictwo Naukowe, Warszawa-Łódź, s. 357-374.

Majewska G. (1997), Stare Miasto w Kutnie i problemy jego ochrony w latach 1945-199o, „Kutnowskie Zeszyty Regionalne”, 1, s. 95-139.

Małowiecki R. (1995), Barokowy kościót w Bieżuniu. Uwagi o architekturze, „Bieżuńskie Zeszyty Historyczne", 5, s. 45-58.

Michalski J. (1974), Andrzej Zamoyski, „Szkice Legnickie”, 8, s. 5-17. 
Mossakowski S. (1973), Tylman z Gameren. Architekt polskiego baroku, Zakład Narodowy im. Ossolińskich, Wrocław-Warszawa-Kraków-Gdańsk.

Mossakowski S. (20I2), Tylman z Gameren (I63I-I706). Twórczość architektoniczna $w$ Polsce, Wydawnictwo Dig, Warszawa-Monachium-Berlin.

Mróz J. (200I), Ptyty kominkowe i piece z żeliwa, „Cenne Bezcenne Utracone”, I (25), s. 8-9.

Niesiecki K. (1743), Korona Polska Przy Ztotey Wolnosci Starożytnemi Rycerstwa Polskiego y Wielkiego Xięstwa Litewskiego Kleynotami, Naywyższemi Honorami, Heroicznym Męstwem, y odwaga, wytworna Nauka, a naypierwy Cnota, Pobożnościa y Swiatobliwością Ozdobiona. Potomnym zaś wiekom na zaszczyt y nieśmiertelna stawę pamiętnych w tey Oyczyznie Synow Podana, t. IV, [Lwów].

Nowak T. (20II), Kutno i Łąkoszyn do schytku XVI wieku, [w:] J.Szymczak (red.), Kutno poprzez wieki, t. I, Prezydent Miasta Kutno, Miejska i Powiatowa Biblioteka Publiczna im. Stefana Żeromskiego, Polskie Towarzystwo Historyczne. Oddział w Łodzi, Kutno-Łódź, s. I3I-175.

Orłowski R. (1965), Dziatalnośćspoteczno-gospodarcza Andrzeja Zamoyskiego (1757-1792), Uniwersytet Marii Curie-Skłodowskiej, Lublin.

Osiński J.H.(1777), Fizyka doświadczeniami potwierdzona przez (...) krotko zebrana, Warszawa.

Pacuski K. (2009), Możnowtadztwo i rycerstwo ziemi gostynińskiej w XIV i XV wieku. Studium z dziejów osadnictwa i elity wtadzy na Mazowszu średniowiecznym, Wydawnictwo Neriton, Instytut Historii PAN, Warszawa.

Parol J. (2019), Mikołaj z Kutna wojewoda łęczycki i starosta generalny wielkopolski (ok. I430-I493), Łódź (wydruk komputerowy pracy doktorskiej udostępniany przez Autora, również w zbiorach Biblioteki Uniwersytetu Łódzkiego).

Pietrzak J. (2002), Badania archeologiczne miasta Kutna i ich perspektywy, „Kutnowski Biuletyn Muzealny", i, s. 55-78.

Pietrzak J. (2003), Zamki i dwory obronne w dobrach państwowych prowincji wielkopolskiej. Studium z dziejów państwowych siedzib obronnych na przetomie średniowiecza i nowożytności, Inicjał, Łódź.

Pietrzak J. (2013), Nowożytne budownictwo przemystowe w dobrach biskupich na Mazow$s z u$, Instytut Archeologii Uniwersytetu Łódzkiego, Łódź.

Poliński D. (2018), Gród czy zamek? Desygnaty terminów oraz konsekwencje ich stosowania w archeologii historycznej i ochronie zabytków, „Archaeologia Historica Polona”, 26, s. 4I-58, https://doi.org/I0.12775/AHP.20I8.003

Powiat kutnowski (1954), D. Kaczmarzyk (oprac.), [w:] Katalog Zabytków Sztuki w Polsce, t. II, J.Z. Łoziński (red.), Województwo tódzkie, Państwowy Instytut Sztuki, Warszawa, S. $25-40$.

Romaniuk P.P. (200I), Sottohub (Ursyn Dwoyna Sottohub) Jan Michat h. Prawdzic (zm. 1748), [w:] Polski Stownik Biograficzny, t. XL.3, Zakład Narodowy im. Ossolińskich, Warszawa-Kraków, s.309-315.

Sikorska A.M.(199I), Wiejskie siedziby szlachty polskiej z czasów saskich, Ośrodek Dokumentacji Zabytków, Warszawa.

Stasiak P.A. (20I2), Rozwój przestrzenny i zabytki miasta, [w:] J. Saramonowicz, P.A.Stasiak, Kutno. Przesztość i wspótczesność, Księży Młyn Dom Wydawniczy, Łódź. 
Szewczyk J. (2009), Uwagi o tematyce pieców i kominów w staropolskim piśmiennictwie XVI-XVIII wieku, na tle okresów późniejszych, „Ciechanowiecki Rocznik Muzealny”, 5.I, s. $49-68$.

Szewczyk J. (2011), Piec i komin w tradycyjnym budownictwie ludowym Podlasia, Oficyna Wydawnicza Politechniki Białostockiej, Białystok.

Szewczyk J. (2012), Piece wschodniej Europy jako fenomen architektoniczny i kulturowy, na podstawie dawnej literatury anglojezycznej, Oficyna Wydawnicza Politechniki Białostockiej, Białystok.

Szyrwid K. (1677), Dictionarium Trium Lingvarum, In usum Studiosae Iuventutis, Vilnae.

Tatarkiewicz W. (1937), Świack. Zabytek dekoracji malarskiej z epoki stanistawowskiej, [w:] Studia do dziejów sztuki w Polsce, t. IV.2, Wydawnictwo Zakładu Architektury Polskiej i Historii Sztuki Politechniki Warszawskiej, Warszawa, s. 5-30.

Tatarkiewicz W.(1966), Świack. Zabytek dekoracji malarskiej z epoki stanistawowskiej, [w:] W. Tatarkiewicz, O sztuce polskiej XVII i XVIII wieku. Architektura. Rzeźba, Państwowe Wydawnictwo Naukowe, Warszawa, s. 206-227.

Tłoczek I. (1985), Dom mieszkalny na polskiej wsi, Państwowe Wydawnictwo Naukowe, Warszawa.

x.R.F. (1894), Wizyty kanoniczne w Archidjecezji Warszawskiej (dok.), „Przegląd Katolicki”, 38 (20 września), s. 599-600.

Żerek-Kleszcz H.(2002), Stanistaw Gadomski - wtaściciel dóbr kutnowskich, ostatni wojewoda tęczycki, „Kutnowski Biuletyn Muzealny”, I, s. II5-I29.

\section{Summary}

Source records concerning the history of Kutno in the period prior to the end of the eighteenth century are scarce. Moreover, only a few of them mention information about the manor located there, and if they do so, they usually only confirm its existence. Exceptions include three records from $\mathrm{I}_{503}$ (or 1502 ) and 1695 , but in their case too the amount of information provided differs.

The first of the three records tells us that the Voivode of Rawa, Andrzej of Kutno, upon deciding about the future division of his goods and possessions between his sons, appointed the central seat of one of the holdings to be half of the town of Kutno with the entire manor house or fortalice (curia seu fortalicio), that is, a residential-defensive building.

The second source (1695) gives us a lengthy description of the manor and grange complex located on the banks of the river Ochnia, made a few years after it was taken over by the Zamoyskis from the Kucienskis family. The third record (also 1695) complements this with information related to the renovation and building works conducted here at the end of the seventeenth century.

The Kutno manor and grange complex at the time consisted of a number of old buildings, most of them in need of renovation or under reconstruction, only rarely new ones, almost all of them wooden; they were partly surrounded by a fence and a palisade made of poles and beams. Within this area stood the old, partly rebuilt, one-storey manor 
with corner extensions. Its rectangular corpus housed five or six chambers laid out in three (at least partly) two-bay lanes. At its corners were four extensions, one of which had a second storey. The porch located at the main entrance was also raised. As a result, the entirety of the structure recalled forms known from, among others, the projects of Battista Gisleni and Tylman van Gameren. The other residential building possibly served the needs of the leaseholders of the goods. It housed five chambers laid out in three, partly two-bay lanes. Next to them, within the grange yard were two residential-farm buildings (budowanie kuchenne and budowanie folwarczne), one industrial farm building (a brewery with ozdownia, where malt was dried) and a few others serving as strictly farming-related buildings. The latter included a granary; a vaguely described building housing a stable; a cowshed that could have a single large building housing an oxshed and seven pigpens or a complex of separate buildings grouped around a small, internal yard; and such a complex of a threshing floor with a shed and two barns.

The only brick building within the grange perimeter, described as zamek stary na kopcu murowany pusty, w oknach niektórych kraty sażelazne (an old castle on a mound, made of bricks and empty, with iron bars in some windows), differed markedly from all these buildings. This building, unused then, was arguably a brick defensive manor raised in the sixteenth century, situated on a mound that may have been a relic of the old fortalicium.

A few other buildings that belonged to the manor were located beyond the main yard of the complex. Four of them were industrial farm buildings (second brewery, horse mill, brickworks, watermill), the fifth one was a service building (inn). The first three were adjacent to the grange, whereas the fourth one was situated west of the city, at some distance from the grange, near a pond on the river Ochnia, and the last one was in the centre (?) of the town.

We do not know what happened to this complex later, but there are no grounds to establish an exact date for its dismantling. It is possible that the latter was related to the construction of a new manor house, surviving to this day (though extensively rebuilt), in the nearby Gieralty in the second half of the $18^{\text {th }}$ or early $19^{\text {th }}$ century, and to the construction of new grange buildings north of town.

Keywords: Middle Ages, Early Modern Period, Kutno, manor house, corner extensions, grange, residential buildings, residential farm buildings, farm buildings, industrial farm buildings, service buildings

\author{
Janusz Pietrzak \\ Uniwersytet Łódzki \\ Wydział Filozoficzno-Historyczny \\ Instytut Archeologii \\ e-mail: janusz.pietrzak@uni.lodz.pl
}

() by the author, licensee University of Lodz - Lodz University Press, Łódź, Poland. This article is an open access article distributed under the terms and conditions of the Creative Commons Attribution license CC-BY-NC-ND 4.0 (https://creativecommons.org/licenses/by-nc-nd/4.0/) 